\title{
PHARMACOGNOSTICAL, PRELIMINARY PHYTOCHEMICAL SCREENING AND IN VITRO ANTIOXIDANT ACTIVITY OF HYDROMETHANOL EXTRACT OF GORDONIA DIPTEROSPERMA KURZ.
}

\author{
PHAIBIANG LAPASAM*, ANDREW LALTHASANGA, FREDDY TEILANG NONGKHLAW, ZOTHAN PUIA
}

Department of Pharmacy, Regional Institute of Paramedical and Nursing Sciences, Mizoram University, Zemabawk, Aizawl, India. Email: phaibianglapasam14@gmail.com

Received: 15 June 2020, Revised and Accepted: 10 July 2020

\section{ABSTRACT}

Objective: This research is to evaluate the pharmacognostic parameter, phytochemical analysis, and in vitro antioxidant properties of hydromethanol extract.

Method: This study carries out the collection and authentication of the plant, extraction, pharmacognostic study, preliminary phytochemical screening, and antioxidant property of leaves hydromethanol extract were evaluated by scavenging the following free radicals - DPPH (2,2-diphenyl1-picrylhydrazyl), hydrogen peroxide, nitric oxide, and reducing power. One-way analysis of variance (ANOVA) followed by Dunnett's test was performed. The minimum value of ${ }^{*} \mathrm{p}<0.05$ considered as significant, ${ }^{* *} \mathrm{p}<0.01$ and ${ }^{* * *} \mathrm{p}<0.001$

Results: Powder microscopy of the leaves showed the presence of stomata, calcium oxalate crystals, trichome, fibers, and oil glands. The total ash was considered to be $3.75 \%$, water-soluble ash $1.25 \%$, and acid-soluble ash 3\%. Hydromethanol (3:7) extract yielded 38.8\%, moisture content 15.6\%. Preliminary phytochemical screening of the extract showed the presence of carbohydrates, glycoside, saponin, phenol, tannin, flavonoid, and steroid. The total flavonoid content was considered to be $32.25 \mathrm{mg} / \mathrm{g}$ of quercetin and the total phenolic content of the extract was found $610 \mathrm{mg} / \mathrm{g}$ of gallic acid. The $\mathrm{IC}_{50}$ radical scavenging effect of extract and gallic acid was considered to be 3.62 and 3.46 for 2,2-diphenyl-1-picrylhydrazyl, 10.4 and 24.73 for hydrogen peroxide, and 48.76 and 58.83 for nitric oxide.

Conclusion: The phytochemical constituents of the extract were well-known pharmacologically active chemicals and significant antioxidant potential was shown by the extract. This study finds out the rationality of the use of this plant as a medicinal plant. Further studies would be needed to explore their potential as a treatment for fever, diarrhea, and dysentery.

Keywords: Gordonia, Meghalaya, Antioxidants, Free radicals, Pharmacognostical parameters, Extraction.

(c) 2020 The Authors. Published by Innovare Academic Sciences Pvt Ltd. This is an open access article under the CC BY license (http://creativecommons. org/licenses/by/4. 0/) DOI: http://dx.doi.org/10.22159/ajpcr.2020.v13i10.38754

\section{INTRODUCTION}

Nature has got a complete storehouse of remedies to cure all ailment of humankind. Since prehistoric, humans have roamed the earth in search of food and they have learned through their experienced which can be edible and which are not [1]. Traditional medicine is popularly practiced in a different part of the world, especially people residing in remote areas, they depend on traditional medicine as their first line of service for health care. Various natural sources are utilized, such as plants, animals, microorganisms, and marine organisms, in medicine to alleviate and treat diseases [2]. According to the WHO, traditional medicine includes diverse health practice, approach knowledge and beliefs, incorporating plants, animals, and/or mineral-based medicines, spiritual therapies, manual techniques, and exercise which can be used to maintain well-being as well as to treat, diagnose, or prevent illness [3].

Gordonia is a genus of flowering plants, family - Theaceae, related to Franklinia, Camellia, and Stewartia of roughly 40 species. G. dipterosperma Kurz. is an evergreen tree growing to 10-20 m tall. They are discovered in the East Himalayas, Nepal to Northeast India, China, Virginia, Florida, and Louisiana [4-6]. The species is adapted to acidic soils. They required high rainfall. The flowering time is in the late winter to early spring $[7,8]$.

Free radicals are substances which are highly reactive and unstable that are produced in the body as a by-product of metabolism or exposure to toxins in the environment such as tobacco, smoke, and ultraviolet light since they are unstable, they tend to donate or accept an electron from another molecule, therefore, they act as oxidants or reluctant which lead to chains reaction which damage cell of an organism. An antioxidant is a molecule that terminates the chain reaction to balance the oxidative stress the plants and animals produce their antioxidant molecules such as glutathione, enzymes, or the dietary antioxidant; Vitamin C and Vitamin E [9].

G. dipterosperma Kurz. is used as a medicinal plant by Jaintia tribal people of Meghalaya, India, both bark and leaves are prepared by simple decoction and filtered, the filtrate is orally consumed for the treatment of fever, diarrhea, and dysentery. Since the plant is not properly documented, pharmacognostic studies are performed for standardization and quality control of the leaves. Phytochemical screening is important to find out the presence of active constituents present in the leave which gives the therapeutic response.

The present study has been made to evaluate the pharmacognostic parameter, preliminary phytochemical screening, total phenolic content, total flavonoid content, and in vitro antioxidant activity of hydromethanolic extract of $G$. dipterosperma Kurz. leaves.

\section{MATERIALS}

\section{Collection of plants}

The leaves of G. dipterosperma Kurz. were collected in July 2019 from Khlookynrin village, Meghalaya, India. The leaves were subsequently processed cleaned, washed to remove dust, and unwanted matter then shade dried and pulverized into coarse powder for extraction. 


\section{Authentication}

The plant was gathered during the flowering seasons for preparing the herbarium sheet and identified by Dr. Chaya Deori (scientist in charge) Botanical Survey of India, Shillong, bearing a voucher specimen no. (BSI/ERC/Tech/2019-20/200).

\section{Macroscopical evaluation}

Macroscopical study is the morphological description of the leaf which can be seen by naked eyes and it was performed by following the standard methods to determine the shape, size, color, and odor of the leaves of G. dipterosperma Kurz. [10].

\section{Microscopical evaluation}

Microscopical evaluations are the histological character of the organized drug and it was made on a qualitative basis [10].

\section{Transverse section of leaves}

A fine section of the leave was cut with a razor blade and mounted in a glass slide with a drop of glycerin, covered with a coverslip, place the slide on the stage of Digital Microscope (Truechrome-2) Zeiss, and observed using $10 \mathrm{X}$ and $45 \mathrm{X}$ lens, each distinguishes character was noted down.

\section{Powder microscopy}

For powder analysis, the shade-dried leaves were pulverized and passed through sieve no. 40. This was observed under a Digital Microscope (Truechrome-2) Zeiss for the presence of plant's components such as stomata, trichome, fibers, starch, and calcium oxalate crystals.

\section{Physicochemical parameters}

Determination of ash value

A $4 \mathrm{~g}$ of powder drug was taken in a tarred silica crucible and incinerated at $450^{\circ} \mathrm{C}$ in muffle furnace till the ash was free from carbon or it becomes white or pale white. The crucible was cooled in a desiccator and weighed. The percentage of total ash was calculated regarding airdried drugs $[11,12]$.

$$
\% \text { Total ash }=\frac{X-Y}{N} \times 100
$$

Where,

$\mathrm{X}=$ The weight of crucible dish + ash obtained

$\mathrm{Y}=\mathrm{The}$ weight of the empty dish

$\mathrm{N}=$ Weight of crude drug taken

\section{Acid-insoluble ash}

The total ash was boiled with $25 \mathrm{ml}$ of $2 \mathrm{~N} \mathrm{HCl}$ for $5 \mathrm{~min}$, filtered with ashless filter paper, washed the insoluble matter with hot water, and incinerated at $450^{\circ} \mathrm{C}$ in a muffle furnace. Then, it was cooled in a desiccator. The weight of the remaining ash was taken. The percentage of acid-insoluble ash was calculated regarding the air-dried drug.

$$
\% \text { Acid }- \text { insoluble ash }=\frac{X-Y}{N} \times 100
$$

Where,

$\mathrm{X}=$ The weight of crucible dish + ash obtained

$\mathrm{Y}=\mathrm{The}$ weight of the empty dish

$\mathrm{N}=$ Weight of crude drug taken

\section{Water-soluble ash}

The total ash was boiled with $25 \mathrm{ml}$ of water for $5 \mathrm{~min}$, filtered with ashless filter paper, washed the insoluble matter with hot water, and then ignited in muffle furnace not exceeding $450^{\circ} \mathrm{C}$. The weight of insoluble matter was subtracted from total ash; the percentage of water-soluble ash was calculated regarding the air-dried drug.

$$
\% \text { Water }- \text { soluble ash }=\frac{X-Y}{N} \times 100
$$

Where,

$\mathrm{X}=$ The weight of crucible dish + ash obtained

$\mathrm{Y}=$ The weight of the empty dish

$\mathrm{N}=$ Weight of crude drug taken

\section{Determination of moisture content}

A $5 \mathrm{~g}$ of the powder crude drug was taken in a tarred porcelain dish and dried in the oven for $5 \mathrm{~h}$ at $100-105^{\circ} \mathrm{C}$, cooled in a desiccator, and weighed. The percentage of loss on drying was calculated regarding the air-dried drug [13].

$$
\text { \%oisture content }=\frac{X-Y}{N} \times 100
$$

Where,

$\mathrm{X}=$ The weight of porcelain dish + crude drug obtained

$\mathrm{Y}=\mathrm{The}$ weight of the empty porcelain dish

$\mathrm{N}=$ Weight of crude drug taken

\section{Fluorescence analysis}

A small quantity of powder drug was treated with various reagents and observed in visible light, under UV with short wavelength $(254 \mathrm{~nm})$ and long wavelength $(365 \mathrm{~nm}$ ). The color observed by application various reagents in different radiation was recorded [14,15].

\section{Extraction}

The leaves of G. dipterosperma Kurz. were extracted by maceration using hydromethanol (3:7) as a solvent. A $250 \mathrm{~g}$ of coarse powder was taken and place in a stoppered container, the solvent was added till the powder drug submerged in the solvent and kept for 3 days with frequent agitation, filtered with filter paper to separate the powder particle from the filtrate. The extract was concentrated using a rotary evaporator (RV-8. IKA) and the obtained extract was dried in a water bath till it becomes viscous and further dried at room temperature [16].

\section{Preliminary phytochemical screening}

The hydromethanol leaf extract was analyzed with various tests to find out the phytoconstituent such as alkaloids, carbohydrate, phenolic, flavonoid, glycosides, saponin, protein, and amino acid [17].

\section{Total phenolic content}

The total phenolic content of the extract was performed spectrophotometrically according to the Folin-Ciocalteu method. A $1 \mathrm{ml}(50 \mu \mathrm{g} / \mathrm{ml})$ of extract treated with $5 \mathrm{ml}$ of Folin's reagent (10fold dilution), after $4 \mathrm{~min}, 4 \mathrm{ml}$ of $20 \%$ sodium carbonate was added, kept in dark at room temperature for 1 hour, and the absorbances were measured at $750 \mathrm{~nm}$. Gallic acid was used as a reference standard. The total phenolic content was quantified by a calibration curve obtained by measuring the absorbance of the known concentration of gallic acid $[18,19]$.

\section{Total flavonoid content}

The total flavonoid content was determined using the aluminum chloride $\left(\mathrm{AlCl}_{3}\right)$ colorimetry assay. To $1 \mathrm{ml}$ of extract, $2 \mathrm{ml}$ of methanol, $3 \mathrm{ml}$ of $5 \%$ sodium nitrite, and $0.3 \mathrm{ml}$ of $10 \%$ aluminum chloride were added and kept for 6 minutes. A $2 \mathrm{ml}$ of sodium hydroxide (1 M) was added and the volume was made up to $10 \mathrm{ml}$ with methanol and kept for 1 hour at room temperature. The absorbance was measured at $510 \mathrm{~nm}$, the total flavonoid content was expressed as mg quercetin equivalent per gram of leaves of G. dipterosperma Kurz. [18,19].

\section{In vitro antioxidant activity}

DPPH radical scavenging activity

DPPH radical scavenging activity was carried out as described by Shimada et al. (1992). A $1 \mathrm{ml}$ of different concentrations of the extract was mixed with $5 \mathrm{ml}$ freshly prepared $0.1 \mathrm{mM}$ of DPPH. The reaction mixture was kept in the dark for $50 \mathrm{~min}$ at room temperature. Ascorbic acid was used as a reference standard. The absorbance 
was measured at $517 \mathrm{~nm}$. Radical scavenging activity of DPPH was calculated [20]

$$
\text { Scavenging effect }(\%)=\frac{\begin{array}{l}
\text { Absorbance of control }- \\
\text { Absorbance of extract }
\end{array}}{\text { Absorbance of control }} \times 100
$$

\section{Nitric oxide scavenging activity}

The extract was prepared at a concentration of $20-100 \mu \mathrm{g} / \mathrm{ml}$ and stored at $4^{\circ} \mathrm{C}$. Griess reagent was prepared by mixing an equal amount of $1 \%$ sulfanilamide in $2.5 \%$ phosphoric acid and $0.1 \%$ naphthyl ethylenediamine dihydrochloride in $2.5 \%$ phosphoric acid immediately before used. A $0.5 \mathrm{ml}$ of $10 \mathrm{mM}$ sodium nitroprusside which was previously dissolved in phosphate buffer saline was taken and to this, $1 \mathrm{ml}$ of different concentrations of the hydromethanol extract was added, incubated at $25^{\circ} \mathrm{C}$ for $180 \mathrm{~min}$ after incubating the extract was mixed with an equal volume of freshly prepared Griess reagent. Control was prepared to add all the reagents instead of extract, methanol was added. The absorbance was measured at $546 \mathrm{~nm}$ [21].

$$
\text { Scavenging effect }(\%)=\frac{\begin{array}{l}
\text { Absorbance of control } \\
\text { Absorbance of extract }
\end{array}}{\text { Abstrol }} \times 100
$$

\section{Hydrogen peroxide scavenging activity}

Hydrogen peroxide solution $(40 \mathrm{mM} / \mathrm{L})$ was prepared in phosphate buffer ( $\mathrm{pH}-7.4)$. A $0.6 \mathrm{ml}$ of prepared hydrogen peroxide solution was taken and to this, $1 \mathrm{ml}$ of different concentrations of the extract was added, keep for $10 \mathrm{~min}$ at room temperature, the absorbance was observed at $230 \mathrm{~nm}$ [22].

$$
\text { Scavenging effect }(\%)=\frac{\begin{array}{l}
\text { Absorbance of control } \\
\text { Absorbance of extract }
\end{array}}{\text { Absance of control }} \times 100
$$

\section{Reducing power assay}

The hydromethanolic extract was diluted at different concentrations (20, $40,60,80$, and $100 \mu \mathrm{g} / \mathrm{ml}$ ). A $1 \mathrm{ml}$ of each dilution was mixed with $2.5 \mathrm{ml}$ of phosphate buffer ${ }_{\mathrm{p}} \mathrm{H}-6.6$ ) and $2.5 \mathrm{ml}$ of $1 \%$ potassium ferricyanide. The mixture was incubated at $50^{\circ} \mathrm{C}$ for $30 \mathrm{~min}$. After cooling, $2.5 \mathrm{ml}$ of $10 \%$ TCA was added and centrifuge for $10 \mathrm{~min}$ at $3000 \mathrm{rpm}$ (rotation/ minute). A $2.5 \mathrm{ml}$ of supernatant was diluted with $2.5 \mathrm{ml}$ of distilled water, to this add $0.5 \mathrm{ml}$ of freshly prepared $0.1 \%$ ferric chloride solution and mixed. The absorbance of the mixture was measured at $700 \mathrm{~nm}$ and recorded. Ascorbic acid was used as a reference standard. The higher absorbance indicates an increase in reducing power [22].

\section{Statistical analysis}

All measurements were taken in triplicates for each sample which was shown as Mean \pm SEM. Statistical analysis was carried out using oneway analysis of variance (ANOVA) followed by Dunnett's test. $\mathrm{p}<0.05$ was considered statistically significant ${ }^{*} \mathrm{p}<0.05$ and ${ }^{* *} \mathrm{P}<0.01$ when compared with control. All analyses were done with the statistical software GraphPad InStat.

\section{RESULTS}

\section{Macroscopical characters}

The morphological characteristic of the leaves shown in Fig. 2, it shows that the leaves have green color on both sides, the petiole is $0.5-1 \mathrm{~cm}$ in length, the midrib is prominent, the venation of the leaves is not prominent, the leaves are $6-15 \mathrm{~cm}$ in length and $3.5-5.5 \mathrm{~cm}$ in wide, it has a smooth surface with an elliptical shape and acuminate apex, the margin of the leaves is entire/denticulate, the leaves are odorless.

\section{Microscopical evaluation}

A fine transverse section of the fresh leaves shows the anatomy of the leaves such as lower epidermis, sclerenchyma, phloem, xylem, collenchyma, palisade, and the upper epidermis, as shown in Fig. 3.

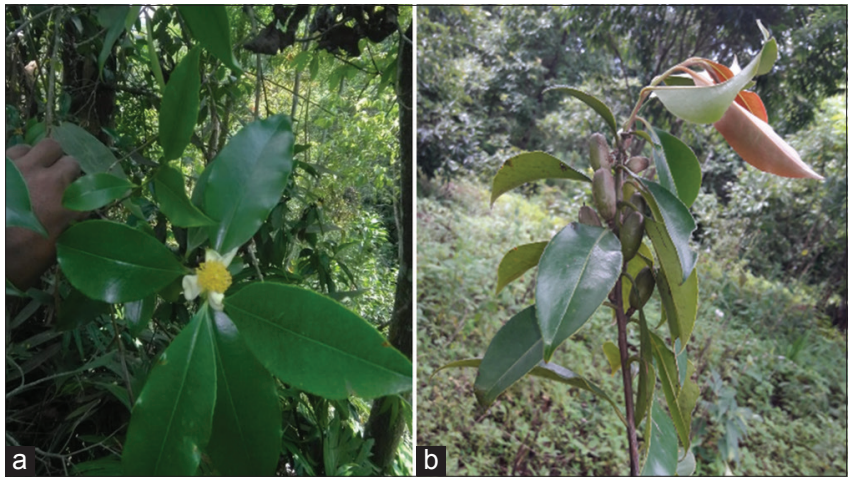

Fig. 1: (a) Flower and leaves, (b) fruit and leaves of Gordonia dipterosperma Kurz. (Theaceae)

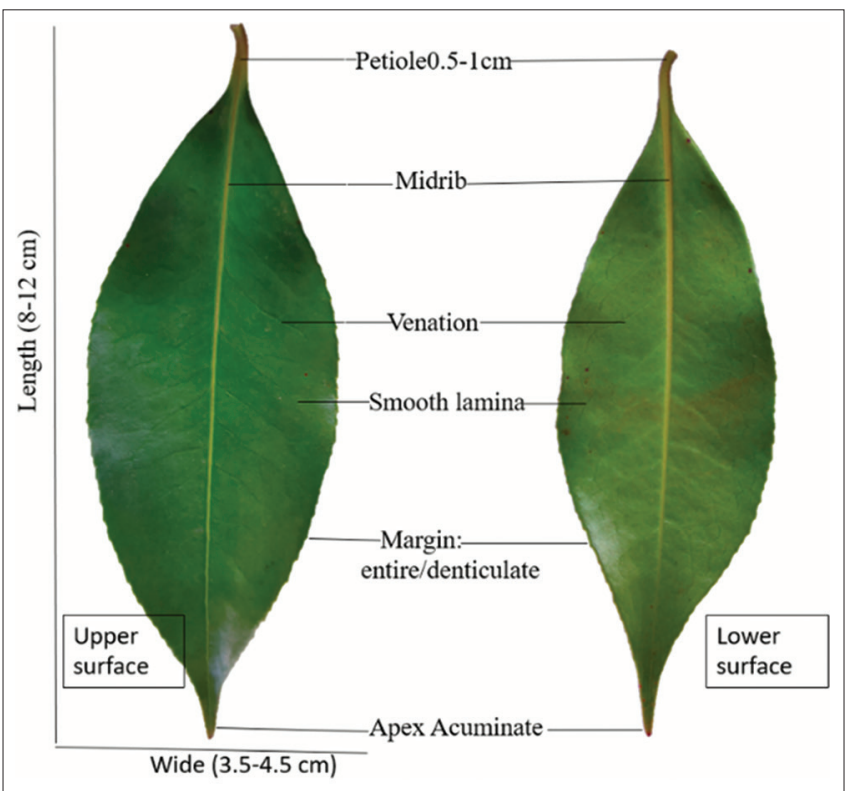

Fig. 2: Organoleptic and morphological characteristics of the leaf of Gordonia dipterosperma Kurz

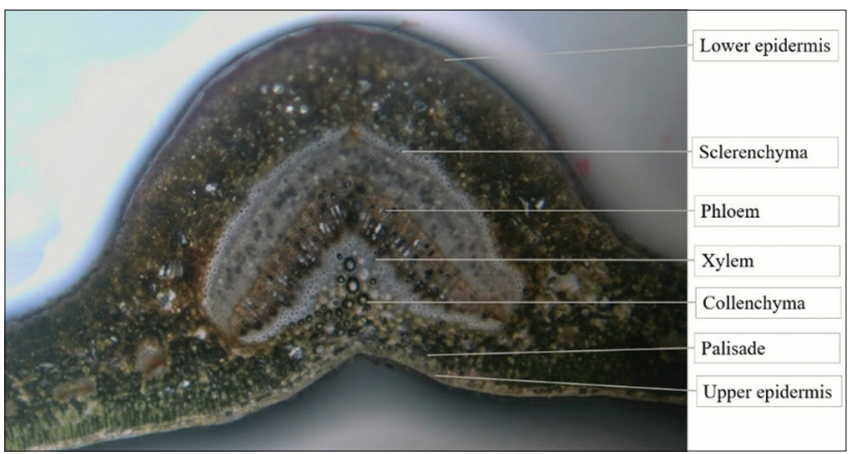

Fig. 3: T. S of leave of Gordonia dipterosperma Kurz. shows the anatomy of the leaves

\section{Powder microscopy}

Powder microscopy of the leaves identified the different components of the leaves, such as stomata, trichome, fibers, calcium oxalate crystal, and an oil gland, as shown in Fig. 4.

Physicochemical evaluation

Ash value of leaves powder 
Moisture content

The moisture content of the leaf powder was found to be $15.6 \% \mathrm{w} / \mathrm{w}$.

\section{Fluorescence analysis}

Fluorescence analysis of power leaves shown in Table 2.

\section{Extraction}

The percentage yield of hydromethanol (3:7) extracts was found to be $38.8 \% \mathrm{w} / \mathrm{w}$.

\section{Phytochemical screening}

Phytochemical screening of hydromethanol extract showed positive for carbohydrate, phenols, tannins, flavonoids, glycoside, and saponin, as shown in Table 3.

Symbol (+++) indicates present in high concentration. (++) indicates present in moderate concentration.

Table 1: Percentage of total ash, water-soluble ash, and acidinsoluble ash

\begin{tabular}{lll}
\hline S. No. & Ash value & $\mathbf{\% w} / \mathbf{w}$ \\
\hline 1 & Total ash & 3.75 \\
2 & Water-soluble ash & 1.25 \\
3 & Acid-insoluble ash & 3 \\
\hline
\end{tabular}

Total phenolic content

The total phenolic content of the extract was considered to be $610 \mathrm{mg}$ per gram of gallic acid.

\section{Total flavonoid content}

The total flavonoid content of the extract was found to be $32.25 \mathrm{mg}$ per gram of quercetin.

\section{In vitro antioxidant activity}

DPPH radical scavenging activity

DPPH (2-2-diphenyl-1-picryl-hydrazyl-hydrate) free radical method is an antioxidant assay it is based on an electron transfer that produces a violet solution in methanol. This free radical, stable at room temperature, is reduced in the presence of an antioxidant molecule, giving rise to colorless methanol solution. The percentage inhibition on DPPH radicals of the extracts was compared with the standard ascorbic acid. The study was performed in triplicate. The hydromethanol extract scavenging activities show dose dependent. The $\mathrm{IC}_{50}$ of hydromethanol extract and ascorbic acid is 3.62 and $3.46 \mathrm{mcg}$, respectively, presented in Table 4.

\section{Nitric oxide scavenging activity}

Leaves hydromethanol extracts exhibited antioxidant activity through competing with oxygen to scavenge for the nitrite radical which was generated from sodium nitroprusside at physiological $\mathrm{pH}$ in an aqueous environment. The maximum free radical scavenging activity and

Table 2: Fluorescence analysis of powder leaves

\begin{tabular}{|c|c|c|c|c|}
\hline S. No. & Treatment of powder & Visible light & Short wavelength $U V$ rays $(254 \mathrm{~nm})$ & Long wavelength UV rays (365 $\mathrm{nm}$ ) \\
\hline 1. & Powder as such & Green & Dark brown & Dark green \\
\hline 2. & Powder $+50 \% \mathrm{H}_{2} \mathrm{SO}_{4}$ & Dark green & Greenish-brown & Dark green \\
\hline 3. & Powder $+50 \% \mathrm{HNO}_{3}^{4}$ & Yellow & Greenish-brown & Dark green \\
\hline 4. & Powder $+5 \% \mathrm{KOH}$ & Yellowish-brown & Brownish-green & Dark green \\
\hline 5. & Powder + Methanol & Light green & Brownish-green & Dark green \\
\hline 6. & Powder + 1N HCl & Pale green & Dark brown & Dark brown \\
\hline 7. & Powder + Cold $\mathrm{H}_{2} \mathrm{O}$ & Green & Dark brown & Dark brown \\
\hline 9. & Powder $+\mathrm{Hot}_{2} \mathrm{O}$ & Light green & Dark brown & Black \\
\hline 10. & Powder + $1 \mathrm{~N} \mathrm{NaOH}$ & Reddish-brown & Greenish-brown & Dark green \\
\hline 11. & Powder + Formic acid & Dark green & Greenish-brown & Dark green \\
\hline 12. & Powder + Calcium chloride & Green & Dark brown & Brown \\
\hline 13. & Powder + Ammonia (25\%) & Red & Reddish-brown & Dark brown \\
\hline 14. & Powder + diethyl ether & Green & Brown & Brownish-green \\
\hline 15. & Powder +Acetic acid & Pale yellow & Dark green & Dark green \\
\hline 16. & Powder $+\mathrm{FeCl}_{3}$ & Dark brown & Greenish-brown & Dark green \\
\hline
\end{tabular}
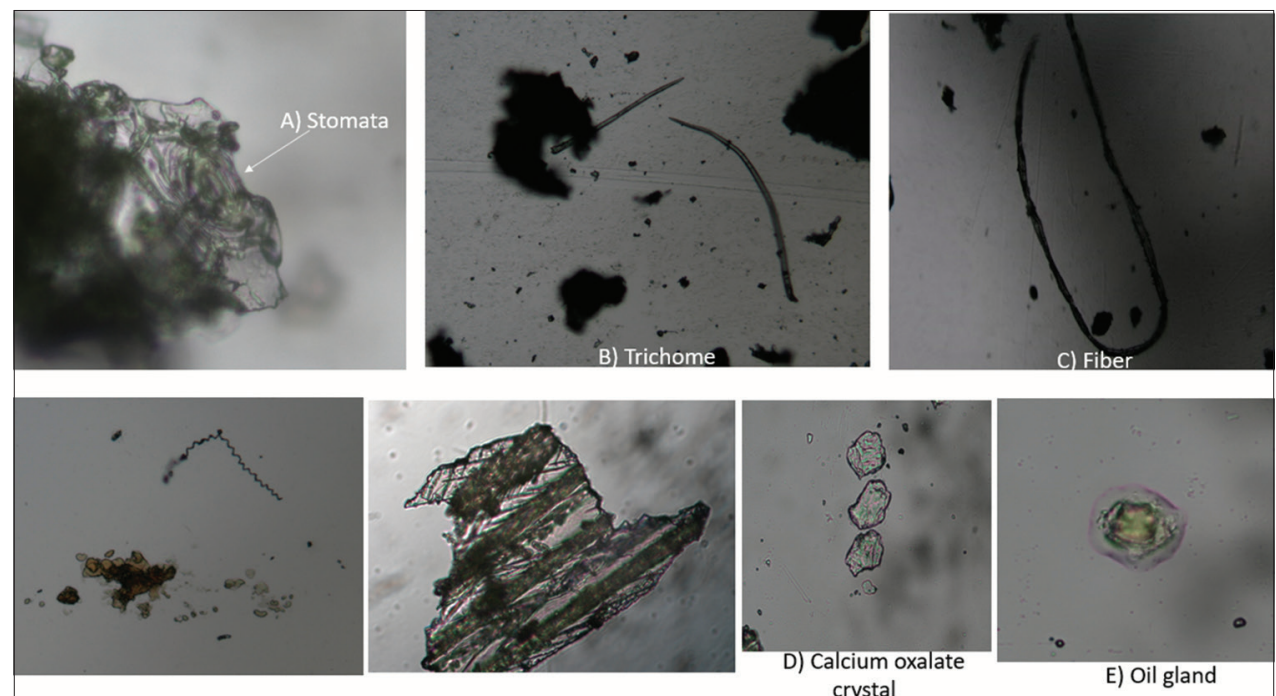

Fig. 4: Powder microscopy of the leaves observed under Digital Microscope (Truechrome-2). All the components are observed using $\times 10$ and $\times 45$ 
Table 3: Phytochemical screening

\begin{tabular}{lll}
\hline S. No. & Phytochemical test & Maceration \\
\cline { 3 - 3 } & & (hydromethanol extract) \\
\hline 1. & Carbohydrates & ++ \\
2. & Phenols and tannins & ++ \\
3. & Flavonoid. & ++ \\
4. & Glycoside & ++ \\
5. & Saponin & +++ \\
\hline
\end{tabular}

Table 4: DPPH radical scavenging activity of hydromethanol extract and standard ascorbic acid

\begin{tabular}{lll}
\hline Concentration & $\begin{array}{l}\text { Ascorbic acid } \\
\text { (Mean } \pm \text { SEM) }\end{array}$ & $\begin{array}{l}\text { Extract } \\
\text { (Mean } \pm \text { SEM) }\end{array}$ \\
\hline 20 & $46.33 \pm 0.08^{* *}$ & $53.30 \pm 0.41^{* *}$ \\
40 & $81.86 \pm 0.30^{* *}$ & $73.48 \pm 0.20^{* *}$ \\
60 & $90.28 \pm 0.15^{* *}$ & $85.75 \pm 0.20^{* *}$ \\
80 & $95.03 \pm 0.08^{* *}$ & $93.48 \pm 0.05^{* *}$ \\
100 & $96.27 \pm 0.02^{* *}$ & $97.92 \pm 0.08^{* *}$ \\
$\mathrm{IC}_{50}$ & $3.46 \mathrm{mcg}$ & $3.62 \mathrm{mcg}$ \\
\hline
\end{tabular}

All values represented as Mean \pm SEM, $n=3$. One-way analysis of variance (ANOVA) followed by Dunnett's test (compare all vs. control) was performed. $\mathrm{p}<0.05$ considered significant, ${ }^{* *} \mathrm{p}<0.01,{ }^{* * *} \mathrm{p}<0.001$.

Table 5: Nitric oxide scavenging activity of methanol extract and gallic acid

\begin{tabular}{lll}
\hline Concentration & $\begin{array}{l}\text { Gallic acid } \\
\text { (Mean } \pm \text { SEM) }\end{array}$ & $\begin{array}{l}\text { Extract } \\
\text { (Mean } \pm \text { SEM) }\end{array}$ \\
\hline 20 & $40.92 \pm 0.748^{* *}$ & $41.71 \pm 0.239^{* *}$ \\
40 & $60.23 \pm 1.743^{* *}$ & $70.33 \pm 0.692^{* *}$ \\
60 & $75.10 \pm 0.598^{* *}$ & $71.90 \pm 0.403^{* *}$ \\
80 & $78.27 \pm 0.951^{* *}$ & $72.74 \pm 0.369^{* *}$ \\
100 & $79.64 \pm 1.741^{* *}$ & $72.43 \pm 1.363^{* *}$ \\
$\mathrm{IC}_{50}$ & $24.73 \mathrm{mcg}$ & $10.41 \mathrm{mcg}$ \\
\hline
\end{tabular}

All values represented as Mean $\pm S E M, n=3$. One-way analysis of variance (ANOVA) followed by Dunnett's test (compare all vs. control) was performed. $\mathrm{p}<0.05$ considered significant, ${ }^{* *} \mathrm{p}<0.01,{ }^{* * *} \mathrm{p}<0.001$.

Table 6: Hydrogen peroxide scavenged activity of hydromethanol extract and standard ascorbic acid

\begin{tabular}{lll}
\hline Concentration & $\begin{array}{l}\text { Ascorbic acid } \\
\text { (Mean } \pm \text { SEM) }\end{array}$ & $\begin{array}{l}\text { Extract } \\
\text { (Mean } \pm \text { SEM) }\end{array}$ \\
\hline 20 & $53.77 \pm 0.016^{* *}$ & $54.69 \pm 0.011^{* *}$ \\
40 & $63.65 \pm 0.016^{* *}$ & $63.83 \pm 0.133^{* *}$ \\
60 & $78.95 \pm 0.092^{* *}$ & $75.33 \pm 0.020^{* *}$ \\
80 & $86.50 \pm 0.021^{* *}$ & $84.50 \pm 0.014^{* *}$ \\
100 & $91.59 \pm 0.021^{* *}$ & $90.24 \pm 0.043^{* *}$ \\
$\mathrm{IC}_{50}$ & $9.44 \mathrm{mcg}$ & $8.29 \mathrm{mcg}$ \\
\hline
\end{tabular}

All values represented as Mean \pm SEM, $n=3$. One-way analysis of variance (ANOVA) followed by Dunnett's test (compare all vs. control) was performed. $\mathrm{p}<0.05$ considered significant, ${ }^{* *} \mathrm{p}<0.01,{ }^{* * *} \mathrm{p}<0.001$

potency are presented in Table 5. The study was performed in triplicate. The hydromethanol extract scavenging activities show dose dependent. The scavenging activity was expressed in terms of percentage inhibition. $\mathrm{IC}_{50}$ values of gallic acid and extract were $24.73 \mu \mathrm{g}$ and $10.41 \mu \mathrm{g}$, respectively.

\section{Hydrogen peroxide scavenging activity}

Hydrogen peroxide itself is not just very reactive but it can be toxic to cells as it provides radicals in the cell. Thus, removing $\mathrm{H}_{2} \mathrm{O}_{2}$ is of great important for the protection of food. The study was performed in triplicate. The hydromethanol extract scavenging activities show dose
Table 7: Rates of reducing power between concentration and absorbance

\begin{tabular}{lll}
\hline Concentration & $\begin{array}{l}\text { Ascorbic acid } \\
\text { (Mean } \pm \text { SEM) }\end{array}$ & $\begin{array}{l}\text { Extract } \\
\text { (Mean } \pm \text { SEM) }\end{array}$ \\
\hline 20 & $0.08 \pm 0.034$ & $0.12 \pm 0.034$ \\
40 & $0.18 \pm 0.003$ & $0.24 \pm 0.030$ \\
60 & $0.25 \pm 0.005$ & $0.44 \pm 0.012$ \\
80 & $0.43 \pm 0.005$ & $0.55 \pm 0.010$ \\
100 & $0.59 \pm 0.005$ & $0.78 \pm 0.033$ \\
\hline
\end{tabular}

All values are represented as Mean \pm SEM, $n=3$.

dependent. The $\mathrm{IC}_{50}$ of hydromethanol extract and ascorbic acid was found to be 8.29 and $9.44 \mathrm{mcg}$, respectively. $\mathrm{H}_{2} \mathrm{O}_{2}$ radical scavenging activity is given in Table 6 .

\section{Reducing power assay}

In this assay, reducing ability was measured by the change of $\mathrm{Fe}^{3+}$ to $\mathrm{Fe}^{2+}$, and the color changes from yellow to dark green when the reaction took place. The absorbance kept increasing with an increase in concentration which shows that the extract has a great potential and electron donor ability for stabilizing free radicals. The reading is given in Table 7.

\section{DISCUSSION}

Pharmacognostical parameters are the first step to evaluate the distinctive character and to establish the identity and quality of crude drugs. In this research work, the macro and microscopical of the leave are studied and the distinctive character of the leaves was identified. Ash value is the remaining residue after incineration of the crude drug which represents inorganic salt which naturally occurred in the crude drug. Ash value is used to determine the quality and purity of crude drugs. The moisture content of crude drugs should be minimal level to discourage the growth of bacteria yeast and fungi during storage, excessive moisture content of crude drugs can lead to decomposition either chemical change or microbial contamination. Fluorescence is a phenomenon exhibited by various chemical constituents present in the plant material. Organic molecules absorbed radiation at a specific range of wavelength and many of them reemit such radiation called luminescence. The phytochemical analysis shows the presence of various secondary metabolites such as phenol, flavonoid, glycoside, and saponin, which are potential for further studies of antimicrobial, anti-inflammatory, and anticancer activity. The total phenolic content and total flavonoid content of a hydromethanol extract are maximum and it shows significant antioxidant potential and it can be viewed as a source for natural antioxidant.

\section{CONCLUSION}

Traditional medicine is most trusted and reliable by many of the population as it has no side effect or less side effect compared to synthetic drugs and safe to take for the long term. The pharmacognostic study such as morphological, microscopical, ash value, and loss on drying is the parameter that helps in identifying the distinctive character of the plant to prevent adulteration and substitution and they are the basic tool for determining the percentage purity of crude drugs. Fluorescence analysis of powder crude drug shows varied fluorescence character which is essential for the standardization of plants. The phytochemical screening of hydromethanol extract finds out the secondary metabolite or bioactive compound present in the leaves of the plant. The hydromethanol extract possesses good antioxidant activity against free radical DPPH, nitric oxide, hydrogen peroxide, and ferric ions $\left(\mathrm{Fe}^{3+}\right)$. The presence of phenol, flavonoid, saponin, tannins, and glycosides supports the rationality of the use of this plant as a medicinal plant. Further studies would be needed to explore their potential as a treatment for fever, diarrhea, and dysentery.

\section{CONFLICTS OF INTEREST}

There are no conflicts of interest or financial support. 


\section{AUTHORS' CONTRIBUTIONS}

All the authors have contributed equally to this research work.

\section{AUTHORS' FUNDING}

This work is completely self-funded.

\section{ACKNOWLEDGMENTS}

I would like to extend my gratitude to the director of RIPANS and to the head of the department of pharmacy for providing the facilities required to run the project smoothly and successfully.

\section{REFERENCES}

1. Yuan H, Ma Q, Ye L, Piao G. The traditional medicine and modern medicine from natural products. Mol MDPI 2016;21:559.

2. Kayang H, Kharbuli B, Myrboh B, Syiem D. Medicinal plants of Khasi Hills of Meghalaya, India. Acta Hort 2005;1:675.

3. Fokunang CN, Ndikum V, Tabi OY, Jiofack RB, Ngameni B, Guedje NM, et al. Traditional medicine: Past, present and future research and development prospects and integration in the national health system of Cameroon. Afr J Tradit Complem 2011;8:3.

4. Tang J, Yu L, Fu H, Li C, Yang J, Zhou W, et al. Cytotoxic triterpenoid saponins from the stems of Gordonia longicarpa. Planta Med 2013;79:353-60.

5. Bartholomew B, Tienlu M. New combinations in Chinese Polyspora (Theaceae). Novon. 2005;15:264-6.

6. Herath HM, Athukoralage PS, Jamie JF. A new oleanane triterpenoid from Gordonia ceylanica. Natl Prod Lett 2001;15:339-44.

7. Orel G, Wilson PG, Curry AS, Luu HT. Two new species of Polyspora (Theaceae) from Vietnam and new combinations for some Asian species. Willdenowia 2013;43:301-8.

8. Fu HZ, Li CJ, Yang JZ, Chen XG, Zhang DM. Triterpenoid glycosides from the stems of Gordonia kwangsiensis. Phytochemistry 2013;85:167-74.

9. Lobo V, Patil A, Phatak A, Chandra N. Free radicals, antioxidants and functional foods: Impact on human health. Pharmacogn Rev
2010;4:118

10. Naik RA, Harisha CR, Acharya RA. A comparative pharmacognostical evaluation of three botanical source plants of jivanti. Int J Pharm Pharm Sci 2018;10:61.

11. Ahmad T, Singh SB, Pandey S. Phytochemical screening and physicochemical parameters of crude drugs: A brief review. Int J Pharm Res Rev 2013;2:53-60.

12. Patel NM. Compendial testing method on herbal crude drug-a review. Asian J Pharm Res 2011;1:49-52.

13. Gautam A, Kashyap SJ, Sharma PK, Garg VK, Visht S, Kumar N. Identification, evaluation and standardization of herbal drugs: A review. Der Pharm Lett 2010;2:302-15.

14. Ranjith D. Fluorescence analysis and extractive values of, herbal formulations used for wound healing, activity in animals. J Med Plant Stud 2018;6:189-92.

15. Kumar M, Mondal P, Borah S, Mahato K. Physico-chemical evaluation, preliminary phytochemical investigation, fluorescence and TLC analysis of leaves of the plant Lasia spinosa (Lour) Thwaites. Int $\mathrm{J}$ Pharm Pharm Sci 2013;5:306-10.

16. Tiwari P, Kumar B, Kaur M, Kaur G, Kaur H. Phytochemical screening and extraction: A review. Int Pharm Sci 2011;1:98-106

17. Pradeepa M, Kalidas V, Geetha N. Qualitative and quantitative phytochemical analysis and bactericidal activity of Pelargonium graveolens L'Her. Int J Appl Pharm 2016;8:7-11

18. Dakshayini PN, Basha PM. Phytochemical screening and in vitro antioxidant potential of Tribulus terrestris fruit and Mesua ferrea flower extracts: A comparative study. Int J Pharm Pharm Sci 2018;10:70-5.

19. Bhati GS, Vaidya X, Sharma P, Agnihotri A. Evaluation of phytochemicals and free radical scavenging behavior in different parts of Syzygium cumini. Int J Curr Pharm Res 2017;9:180-5.

20. Akter MS, Ahmed M, Eun JB. Solvent effects on antioxidant properties of persimmon (Diospyros kaki L. cv. Daebong) seeds. Int J Food Sci Tech 2010;45:2258-64.

21. Boora F, Chirisa E, Mukanganyama S. Evaluation of nitrite radical scavenging properties of selected Zimbabwean plant extracts and their phytoconstituents. J Food Process 2014;2014:918018.

22. Gülçin I, Huyut Z, Elmastaş M, Aboul-Enein HY. Radical scavenging and antioxidant activity of tannic acid. Arab J Chem 2010;3:43-53. 